Original Article

\title{
EPIDEMIOLOGY AND CHARACTERISTICS OF PLASTIC SURGERY CASES IN SIMPANG LIMA GUMUL GENERAL HOSPITAL, KEDIRI REGENCY DURING COVID-19 PANDEMIC
}

\author{
Nathania Carolina Wirawan $\left.{ }^{1 *}\right)$ \& Eko Herihadi² \\ 1. Celina Medika Primary Clinic, Jombang, East Java, Indonesia \\ 2. Department of Plastic Reconstructive and Aesthetic Surgery, RSUD Simpang Lima Gumul Kabupaten Kediri, Kediri, Indonesia
}

\begin{abstract}
Backgrounds: Chinese Government found the first case of coronavirus disease 2019 (COVID-19) in Wuhan, China, in December 2019. The pandemic impacts the number of visits to plastic surgery clinics in many countries such as Italy and the United States following surgical limitations. This study was aimed to determine the impact of the pandemic on the field of Reconstructive and Aesthetic Plastic Surgery in Indonesia, particularly in Kediri Regency, East Java.
\end{abstract}

Methods: The study design was an analytical cross-sectional study, using data obtained from the medical records of plastic surgery patients at SLG General Hospital in Kediri Regency. The data analysis included descriptive analysis and dummy regression analysis.

Results: This study included a total of 29 observations, 14 before the pandemic era and 15 during the pandemic, with a total of 460 individuals from various diagnostic categories. Based on the findings, the number of patients diagnosed with Congenital Disorders, Skin, and Soft Tissue, and Aesthetic Surgery dropped by 7\%, 2\%, and 6\%, respectively. Meanwhile, there was an increased number of patients with Maxillofacial, Burn and Wound Care, and Hand and Microsurgery by $5 \%, 4 \%$, and $1 \%$, respectively.

Conclusions: The average number of patient visits for the Skin and Soft Tissue, Burn and Wound Care, and Hand and Microsurgery categories did not vary much during this pandemic.

Keywords: Plastic Surgery; COVID-19; Cross-Sectional studies

\section{ABSTRAK}

Latar Belakang: Corona Virus disease (COVID-19) pertama kali ditemukan di Wuhan, China pada Desember 2019. Masa pandemi juga memberikan dampak pada angka kunjungan kasus bedah plastik di berbagai belahan dunia seperti di Italia dan Amerika Serikat. Penelitian ini kami lakukan untuk mengetahui dampak pandemi terhadap bidang Bedah Plastik Rekonstruksi dan Estetika di Indonesia khususnya di Kabupaten Kediri, Jawa Timur.

Metodologi: Metode yang digunakan dalam penelitian ini yaitu cross-sectional yang merupakan bagian dari metode survey analitik, dimana data yang digunakan merupakan data sekunder yang berasal dari hasil rekam medis pasien bedah plastik yang ditangani oleh dokter ahli bedah plastik pada RSUD SLG Kabupaten Kediri. Analisis data terbagi menjadi dua bagian yaitu analisis deskriptif dan analisis regresi dummy.

Hasil: Sebanyak 29 observasi yang digunakan dalam penelitian ini yang terdiri dari 14 observasi sebelum masa pandemi dan 15 observasi pada saat masa pandemi dengan 460 sampel pasien dengan kategori diagnosa yang berbeda. Hasil menunjukkan pasien dengan kategori diagnosa Kelainan Kongenital, Skin dan Soft Tissue dan Aesthetic Surgery mengalami penurunan jumlah yaitu masing masing 7\%, 2\% dan 6\%,. Sedangkan untuk pasien dengan kategori diagnosa Maxilofacial, Burn dan Wound Care serta Hand dan Microsurgery mengalami peningkatan masing masing $5 \%, 4 \%$ dan $1 \%$.

Kesimpulan: Rata rata jumlah kunjungan pasien untuk pasien dengan kategori Skin dan Soft Tissue, Burn dan Wound Care serta Hand dan Microsurgery tidak mengalami perubahan rata-rata kunjungan yang signifikan dimasa pandemi.

Kata Kunci: Bedah Plastik; COVID-19; Studi Cross-Sectional

\section{Conflicts of Interest Statement:}

The author(s) listed in this manuscript declare the absence of any conflict of interest on the subject matter or materials discussed. 


\section{INTRODUCTION}

Chinese Government found the first case of coronavirus disease 2019 (COVID-19) in Wuhan, China, in December 2019. ${ }^{1}$ The initial case was discovered at the Huanan seafood market, affecting 41 individuals before spreading to other cities in China and infecting thousands more People's Republic of China individuals. ${ }^{2}$ COVID19 had spread to other countries worldwide within three months. WHO declared COVID-19 as a pandemic on March 11th, 2020.3 In midJanuary, the COVID-19 case was discovered in Thailand, a popular tourist destination for inhabitants of the People's Republic of China. ${ }^{6}$ Meanwhile, the Singaporean Government identified the first case on January 23rd, 2020. ${ }^{7}$ Two first COVID-19 cases were discovered in Jakarta on March 2nd, 2020. ${ }^{3}$ Per June 27th, 2021, COVID-19 has infected 1,115,304 Indonesians while East Java ranked fourth with 165,013 active cases. $^{8}$

The rapid spread of COVID-19 is a challenge for the health system and healthcare workers during this pandemic. ${ }^{9}$ Health professionals are working under the risk of COVID-19 without any effective approved treatment. Surgery has also had an impact. Several published surgery recommendations during the pandemic, ranging from limitations on operating room personnel and the number of patients in the consultation rooms to the online consultation. ${ }^{11-13}$ Every reconstructive and cosmetic plastic surgery case is confronted with the choice of postponing the surgery to minimize COVID-19 transmission, reducing morbidity and death while also protecting healthcare workers. ${ }^{14} \mathrm{~A}$ total of $89.4 \%$ of respondents who were members of InaPRAS chose to stop surgery activities and only perform surgery in emergency cases that require immediate action. ${ }^{3}$ Approximately $76.2 \%$ diverted the emergency treatment with conservative therapy. Meanwhile, 5.8\% of reconstructive and aesthetic plastic surgeons continued to provide health services before the pandemic. $^{3}$

In addition to restrictions on surgery, there were several publications related to plastic surgery patient visits during the pandemic. A study in Italy reported no significant differences before and after the pandemic. ${ }^{15,16}$ Another study conducted in California found a considerable decrease in inpatient visits, particularly for reconstructive and aesthetic plastic surgeons who practice independently. The researcher also obtained 17 Similar results from a study conducted in Rhode Island that there was a 36\% reduction in Plastic Surgery visits. ${ }^{5}$ A survey conducted by Medscape with all statesparticipants showed no significant differences in the visits number. ${ }^{18}$ Data on visits or consultations of plastic surgery patients during the epidemic are still scarce. This study was aimed to determine the impact of the pandemic on the field of Reconstructive and Aesthetic Plastic Surgery in Indonesia, particularly in Kediri Regency, East Java. The results of this study may be used later as an evaluation material for hospitals and plastic surgeons, particularly in SLG General Hospital, Kediri Regency.

\section{METHOD}

\section{Data Sources and Variables}

This study was an analytical cross-sectional study using secondary data derived from patients' medical records treated by reconstructive and aesthetic plastic surgeon experts at SLG Hospital in Kediri Regency. Data retrieved from medical records included age, city of origin, payment method, referral or nonreferral, sex, and diagnostic category. The cases were classified into Congenital Anomalies, Maxillofacial, Skin and Soft Tissue Burn and Wound Care, Hand and Microsurgery, and Aesthetic Surgery. These cases were also grouped based on the period before and during the pandemic. Another classification included before and after universal health coverage.

\section{Data Analysis}

This study aimed to describe the probability of plastic surgery patients visiting the SLG General Hospital in the Kediri Regency. Furthermore, this study compared the categorybased cases between pre-and during the COVID19 pandemic era in Indonesia regarding hospital services. Therefore, the authors conducted a dummy regression analysis to analyze plastic 
surgery patients' medical records. There were two stages, as the following:

\section{a. First Stage}

\section{Descriptive Analysis}

The descriptive analysis evaluated the patient's characteristics from medical record data before and during the COVID-19 pandemic in Indonesia. The definition of the pre-COVID-19 pandemic in Indonesia was January 2019 to February 2020, while the period during the COVID-19 epidemic in Indonesia was limited from March 2020 to May 2021.

\section{b. Second stage}

\section{Dummy Regression Analysis}

Dummy regression analysis was used to evaluate the impact of the COVID-19 pandemic in Indonesia on Congenital Anomalies, Maxillofacial, Skin, and Soft Tissue Burn and Wound Care, Hand and Microsurgery, and Aesthetic Surgery based on hospital services.

\section{RESULTS}

\section{Descriptive Analysis}

This section reported the descriptive analysis results on plastic surgery patients' medical records. These characteristics included the number of patients attending SLG General Hospital in Kediri Regency, based on age, city of origin, payment method, referral or non-referral, sex, and diagnostic category before and during the COVID-19 pandemic.

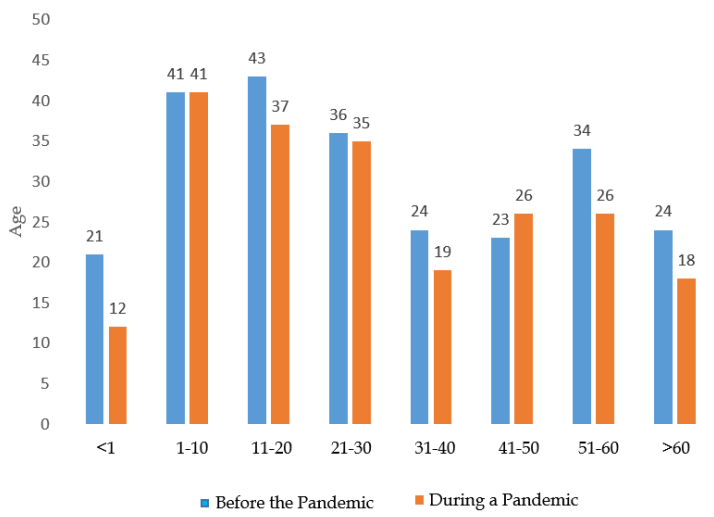

Figure 1. The number of plastic surgery patients based on age before and during the pandemic.

Figure 1 depicts the number of plastic surgery patients by age group pre and during the pandemic. There were eight age groups for a total of 460 patient visits. Two hundred and fourteen patients were visited during the pandemic, and 246 patients see before the pandemic.

Patients aged 11 to 20 had the most significant number of visits to the SLG General Hospital in Kediri Regency, accounting for 17.5\% of all patients in the pre-pandemic era and 9.3 percent of all patients-both during and before the pandemic. Meanwhile, patients under the age of one year had minor visits to the SLG General Hospital in Kediri Regency, comprising 8.5 percent of all patients in the pre-pandemic era and 4.6 percent of all patients during and before the pandemic.

Compared to other age groups, patients aged 1-10 years had the highest number of visits during the pandemic. In contrast, the number of visitors to the SLG General Hospital in Kediri Regency remained consistent, at about 8.9 percent, both during and before the pandemic. However, compared to a total of 246 patients before the pandemic and 214 individuals during the pandemic, the number of patient visits at that age rose by 2.5 percent. The age group under one year had the least visits both during and before the epidemic, accounting for 8.5 percent and 5.6 percent, respectively. During the pandemic, this age group similarly had a 2.9 percent reduction in the number of visits.

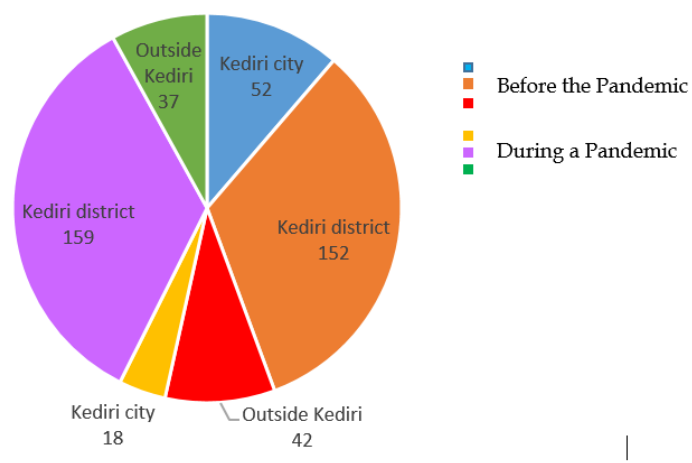

Figure 2. Number of plastic surgery patients based on city of origin before and during the pandemic

Figure 2 illustrates the number of plastic surgery patients who attended the SLG General Hospital in Kediri Regency before and during the epidemic based on the city of origin. The patient's city of birth was classified into three groups: Kediri city, Kediri Regency, and outside of Kediri. 
Patients from Kediri Regency had the highest number of visits, comprising 33\% and $35 \%$ of total patient visits before and during the pandemic, respectively. Meanwhile, patients with addresses outside Kediri in the prepandemic era and patients with lessons in Kediri during the pandemic had the fewest visits.

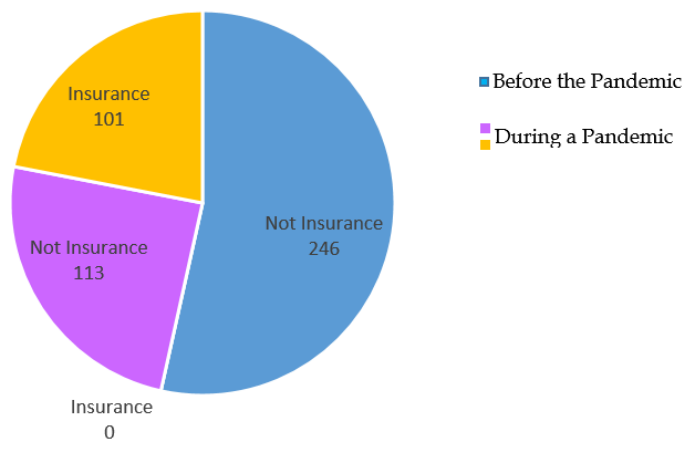

Figure 3. Number of plastic surgery patients based on the method of payment before and during the pandemic

As per Figure 3, the SLG General Hospital in Kediri Regency began health services for patients with universal health coverage when the pandemic started. The number of patients who visited using universal health coverage was 214, with a difference of up to 12 patients, or 5.6 percent, between those who used universal health coverage and those who did not.

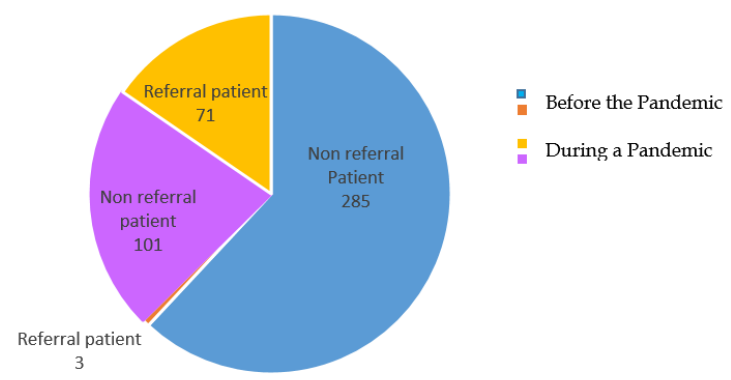

Figure 4. Number of plastic surgery patients based on a referral before and during the pandemic

Figure 4 describes the number of plastic surgery patients based on referrals or nonreferrals. Referrals meant that patients arrived at the hospital with a doctor's referral or came alone without a doctor's referral before and during the epidemic. The number of patients who did not have a doctor's referral predominated, with a very substantial difference of 285 versus three visits or $98 \%$ of patient visits in the pre-pandemic era. The difference between these groups was only modest during the pandemic: 41 percent for the referral group vs. 59 percent for the nonreferral group (30 visits).

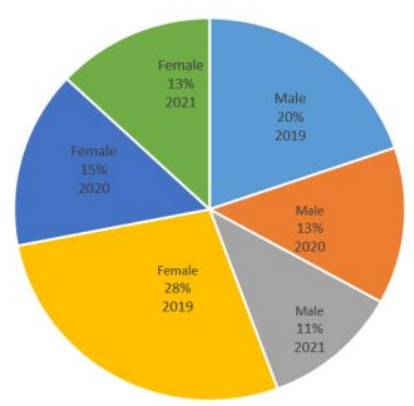

Figure 5. Number of plastic surgery patients based on sex gender in 2019-2021

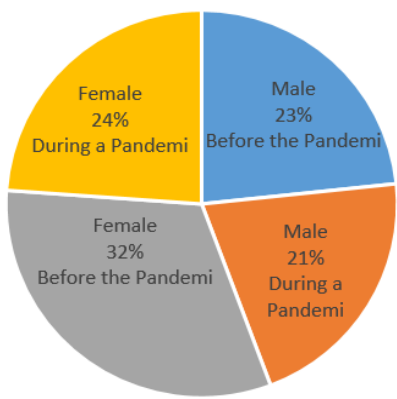

Figure 6. The mean of plastic surgery patients based on sex before and during the pandemic

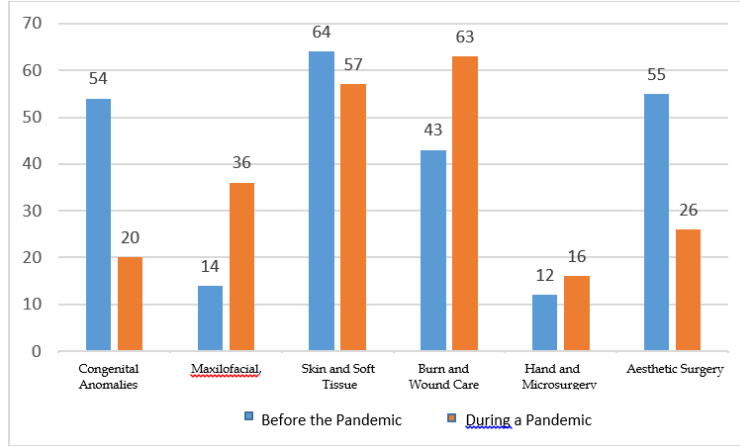

Figure 7. Number of plastic surgery patients based on the diagnostic category before and during the pandemic

Figure 5 demonstrates the number of male and female plastic surgery patients that visited the SLG General Hospital in Kediri Regency between January 2019 and May 2021. There were 460 patients in total. It was observed that in 2019, 2020, and 2021, female patient visits outnumbered male patient visits by 11 percent or 
52 individuals. The year with the highest patient visits was 2019, with 28 percent or 127 female patients and 20 percent or 91 male patients.

However, when the period before and after the pandemic reached Indonesia was included, coexisting with the universal health coverage era (BPJS), the results were presented in Figure 6. Figure 6 demonstrated that the mean difference in the number of hospital visits for male patients during and before the pandemic was less than for female patients, with a difference of $2 \%$ and $8 \%$, respectively.

Figure 7 shows the number of plastic surgery patients based on the diagnostic category before and after the pandemic. Despite the availability of universal health coverage, the number of patients diagnosed with Congenital Anomalies, Skin and Soft Tissue, or Aesthetic Surgery dropped by 7\%, $2 \%$, and $6 \%$, respectively. Meanwhile, patients included in Maxillofacial, Burn and Wound Care, and Hand and Microsurgery categories were increased by $5 \%, 4 \%$, and $1 \%$, respectively.

To determine whether there was a significant difference in the increase or decrease of the mean number of patients with these diagnostic categories before and after the pandemic, the findings were shown in Table 1 :

Table 1. The comparison among the diagnostic categories before the pandemic and during the pandemic

\begin{tabular}{lrrrr}
\hline $\begin{array}{l}\text { Diagnostic } \\
\text { Categories }\end{array}$ & \multicolumn{1}{c}{$\mathrm{F}$} & $\mathrm{t}$ & $\mathrm{df}$ & $\mathrm{P}$-value \\
\hline $\begin{array}{l}\text { Congenital } \\
\text { Anomalies }\end{array}$ & 13.048 & 2.247 & 27 & .033 \\
$\begin{array}{l}\text { Maxilofacial } \\
\text { Skin and soft }\end{array}$ & 8.231 & -2.536 & 27 & .017 \\
tissue & .203 & .520 & 27 & .607 \\
$\begin{array}{l}\text { Burn and } \\
\text { Woundcare }\end{array}$ & 2.156 & -1.250 & 27 & .222 \\
$\begin{array}{l}\text { Hand and } \\
\text { Microsurgery }\end{array}$ & 4.623 & -.344 & 27 & .734 \\
$\begin{array}{l}\text { Aesthetic } \\
\text { Surgery }\end{array}$ & 2.135 & 2.289 & 27 & .030 \\
\hline
\end{tabular}

According to Table 1, the number of patients who visited the SLG General Hospital in Kediri Regency during the pre-pandemic era and during the pandemic period for the Congenital Anomalies, Maxillofacial and Aesthetic Surgery categories was significantly different as the Pvalues $<$ error level $(5 \%$ or 0.05$)(p=0.003, p$
$=0.017$ and $\mathrm{p}=0.030$, respectively). Meanwhile, there were no significant differences in the diagnostic categories of Skin and Soft Tissue, Burn and Wound Care, and Hand and Microsurgery either during or before the pandemic as the P-values $>0.05$.

\section{Dummy Regression Analysis}

This stage evaluated the number of patient visits to the SLG General Hospital in Kediri Regency based on the diagnostic category. Both before- and during-pandemic data were analyzed. The analysis was also conducted based on the period before and after universal health coverage took effect. The confidence interval used in this dummy regression analysis is $95 \%$ (error level $=5 \%$ ), meaning that all $\mathrm{P}$-values obtained will be compared with 0.05 .

Table 2. Number of study samples by month

\begin{tabular}{llrr}
\hline & & \multicolumn{2}{c}{ Percen } \\
Unweighted Cases & $\mathrm{N}$ & \multicolumn{1}{c}{$\mathrm{t}$} \\
\hline Selecte & Included in & 29 & 100.0 \\
d Cases & Analysis & 0 & .0 \\
& Missing Cases & 29 & 100.0 \\
& Total & & \\
\hline \multicolumn{2}{l}{ Unselected Cases } & 0 & .0 \\
\hline \multicolumn{2}{l}{ Total } & 29 & 100.0 \\
\hline
\end{tabular}

Table 2 revealed that the observations lasted 29 months, 14 months before the pandemic, and 15 months later. All of these observations were evaluated. No data was lost, regardless of the diagnosis, service type, or periods of the epidemic. The findings of the analysis are presented in tables 3 and 4 below:

Table 3. A simultaneous test of diagnostic categories

\begin{tabular}{lrr}
\hline Statistic Test & Value & P-value \\
\hline Pillai's Trace & .467 & .020 \\
Wilks' Lambda & .533 & .020 \\
Hotelling's & .877 & .020 \\
Trace & & \\
Roy's Largest & .877 & .020 \\
$\quad$ Root & & \\
\hline
\end{tabular}


Table 4. A partial test of diagnostic category

\begin{tabular}{lrrrr} 
& \multicolumn{2}{c}{$\begin{array}{c}\text { Before } \\
\text { Diagnostic } \\
\text { Categories }\end{array}$} & \multicolumn{1}{c}{$\begin{array}{c}\text { During } \\
\text { Pandemic }\end{array}$} \\
\cline { 2 - 5 } & P-value & B & P-value & \multicolumn{1}{c}{ B } \\
\hline Congenital & .000 & 4.00 & .033 & - \\
Anomalies & & 0 & & 2.667 \\
Maxilofacial & .018 & 1.00 & .017 & 1.400 \\
Skin and Soft & .000 & 4.57 & .607 & - \\
Tissue & & 1 & & 0.771 \\
Burn and & .000 & 3.07 & .222 & 1.129 \\
Woundcare & & 1 & & .210 \\
Hand and & .061 & .857 & .734 & \\
Microsurgery & & & & \\
Aesthetic & .000 & 3.92 & .030 & \\
Surgery & & 9 & & 2.195 \\
\hline
\end{tabular}

The results of the simultaneous test analysis in Table 3, all of the test statistics showed a $\mathrm{P}$-value $<0.05$, indicating that at least one diagnostic category variable affected the mean number of patient visits to the SLG General Hospital, Kediri Regency, both before and during the pandemic. The results of the partial test in Table 4 supported these findings. It was discovered that during a pandemic, the mean number of patients visiting the SLG General Hospital in Kediri Regency with the diagnostic category of Congenital Anomalies, Maxillofacial and Aesthetic surgery were different significantly.

This was indicated by the P-value for each category of $0.033,0.017$ and 0.030 ( $p<0.05)$. Meanwhile, before the pandemic, all diagnostic categories substantially impacted the mean number of patient visits to the SLG General Hospital in Kediri Regency. The Skin and Soft Tissue category had the greatest average number of patient visits to the hospital compared to other categories in the pre-pandemic period, with an average of 4 to 5 individuals each month. Meanwhile, the mean number of patient visits to hospitals with this category dropped by 0.771 during the pandemic, although the pandemic had no significant impact.

\section{DISCUSSION}

The study discovered a significant difference in visits to plastic surgery cases at the SLG General Hospital in Kediri Regency before COVID-19 in Indonesia (January 2019 - February 2020) compared to after COVID-19 in several categories. A mean difference of $11 \%$ based on sex was found where women consulted more plastic surgery cases than men. This was similar to a study conducted in Philadelphia which stated that female visits were higher than male patients. ${ }^{19}$

Universal Health Insurance such as BPJS and Jamkesda, which took effect concurrently with the entry of COVID19 to Indonesia in March 2020, did not increase public interest in having consultations or undergoing plastic surgery in non-emergency or elective cases, such as congenital anomalies (e.g., cleft lip and palate), vascular malformation, hypospadias, syndactyly, skin -soft tissue (e.g., nevus, keloid, basalioma, atheroma, coloboma, and benign tumor), and aesthetic procedures (e.g., facelifts, neck lifts, rejuvenation, blepharoplasty, rhinoplasty, breast implants, and lipolysis). The decrease was $7 \%$ for congenital abnormalities, $2 \%$ for skin and soft tissue, and $6 \%$ for aesthetic procedures. Meanwhile, there was a $5 \%$ increase in cases of trauma needing immediate intervention, led by cases of craniofacial trauma, followed by burns and wound care, which increased by $4 \%$ during the pandemic, and a $1 \%$ increase in cases of hand and microsurgery.

Patients in the pandemic era were dominated by the age range of 1-10 years, whereas patients in the pre-pandemic period were defeated by 11-20 years. Patients having plastic surgery consultations were primarily from Kediri Regency compared to patients from the Kediri city or from outside Kediri; this might be influenced by the location of the SLG General Hospital in Kediri Regency, which was quite far from the Kediri City Hospital, which was located in the city center.

The study's findings also revealed that patients who used universal health coverage were mainly from the Kediri Regency. This was evident during the introduction of universal health coverage, predominated by patients from the Kediri Regency. In addition, the community needed universal health coverage to have treatment at the SLG General Hospital Kediri Regency, particularly for plastic surgery patients, as seen from the number of patients between groups was similar.

The availability of government health insurance services during the pandemic period increased patient referrals from $2 \%$ to $41 \%$. This 
could be attributed to tiered referrals, in which SLG General Hospital in Kediri Regency was a level $C$ hospital. Thus, this hospital received referrals from primary health care facilities as a form of trust from primary care health workers to the ability of plastic surgeons at SLG General Hospital Kediri Regency to provide adequate management.

\section{CONCLUSION}

This study reported the characteristics of plastic surgery patients at the SLG General Hospital in Kediri Regency. These characteristics included the number of patients who visited both before and during the COVID-19 pandemic based on age, payment method, city of origin, sex, and diagnostic category. In terms of age group, female patients had a lower mean number of visits during the COVID-19 pandemic. Meanwhile, the number of patients was predominated by patients from Kediri Regency both before and during the pandemic.

The number of patient visits based on payment methods during and before the COVID19 pandemic was nearly the same. Meanwhile, patients with Congenital Anomalies, Maxillofacial and Aesthetic Surgery cases significantly changed the mean number of visits during the pandemic. In contrast, there was no significant difference in the mean number of visits for patients with Skin and Soft Tissue, Burn and Wound Care, and Hand and Microsurgery cases.

This study was consistent with a previous study conducted in the United States, which reported that during the COVID-19 pandemic, there was a decrease in the number of visits to plastic surgery clinics, both from female and male patients and that this decline occurred primarily in the category of elective cases that could be postponed.

\footnotetext{
Correspondence regarding this article should be addressed to:

Nathania Carolina Wirawan

Celinia Medika Primary Clinic, Jombang, 61462, Indonesia. E-Mail: mfnathaniacw@gmail.com
}

\section{ACKNOWLEDGEMENT}

We want to thank BAKESBANGPOL of East Java Province, the BAKESBANGPOL of Kediri Regency, the Ethics Committee of the SLG Hospital Kediri Regency, Plastic Reconstructive and Aesthetic Surgery Division of the SLG Hospital Kediri Regency, and the Medical Records Division of the SLG Hospital Kediri Regency for the support on the completion of this study.

\section{REFERENCES}

1. MacKenzie EL, Poore SO. Reply: Slowing the Spread and Minimizing the Impact of COVID-19: Lessons from the Past and Recommendations for the Plastic Surgeon. Plast Reconstr Surg. 2021;147(6).

2. Wu YC, Chen CS, Chan YJ. The outbreak of COVID-19: An overview. Vol. 83, Journal of the Chinese Medical Association. 2020.

3. Prasetyono T.O.H. Indonesian plastic surgeons' attitude during the early period of the COVID-19 pandemic. Arch Craniofacial Surg. 2021;22(1).

4. Giunta RE, Frank K, Moellhoff N, Braig D, Haas EM, Ahmad N, et al. The COVID-19 Pandemia and its consequences for plastic surgery and hand surgery. Vol. 52, Handchirurgie Mikrochirurgie Plastische Chirurgie. 2020.

5. Paiva M, Rao V, Spake C.S.L., King VA, Crozier JW, Liu PY, et al. The Impact of the COVID-19 Pandemic on Plastic Surgery Consultations in the Emergency Department. Plast Reconstr Surg - Glob Open. 2021;

6. Marine W, Shaw R. COVID-19 response in Thailand and its implications on future preparedness. Int J Environ Res Public Health. 2021;18(3).

7. Lam W.W.C., Loke KSH, Wong WY, Ng D.C.E. Facing a disruptive threat: how can a nuclear medicine service be prepared for the coronavirus outbreak 2020? Eur J Nucl Med Mol Imaging. 2020;47(7).

8. Satuan Tugas COVID-19. Peta Sebaran COVID-19 [Internet]. [cited 2021 Jun 21]. Available from: https://covid19.go.id/peta-sebaran 
9. Chi D, Chen AD, Dorante MI, Lee BT, Sacks J.M. Plastic Surgery in the Time of COVID19. J Reconstr Microsurg. 2021;37(2).

10. Ozturk CN, Kuruoglu D, Ozturk C, Rampazzo A, Gurunian R. Plastic surgery and the COVID-19 pandemic: A review of clinical guidelines. Ann Plast Surg. 2020;85(2S).

11. Atmodiwirjo P, Ramadan MR, Ralena NA, Triatmoko SE. Microsurgical Reconstruction During COVID-19 Pandemic Setting: A Systematic Review and Clinical Applications. J Plast Rekonstruksi. 2021;8(1).

12. Zine-Eddine I, Elatiqi $O$, Aitbenlaassel $O$, Yafi I, Mahrouch M, Gouatri M E.L., et al. A Moroccan plastic surgery department approach during COVID-19 pandemic. Vol. 74, Journal of Plastic, Reconstructive, and Aesthetic Surgery. 2021.

13. Armstrong A, Jeevaratnam J, Murphy G, Pasha M, Tough A, Conway-Jones R, et al. A plastic surgery service response to COVID-19 in one of the largest teaching hospitals in Europe. Vol. 73, Journal of Plastic, Reconstructive, and Aesthetic Surgery. 2020.

14. Al-Benna S. Concepts of management of plastic surgery services during the coronavirus disease 2019 pandemic. Eur J Plast Surg. 2020;43(6).

15. Marcasciano M, Kaciulyte J, Mori FLR, Lo Torto F, Ribuffo D, Casella D. Plastic surgery in the time of Coronavirus in Italy. Maybe we should say: "Thanks Darwin we are Plastic Surgeons!": Italian Plastic Surgeons facing the Pandemic [Internet]. Vol. 0, Journal of Plastic, Reconstructive, and Aesthetic Surgery. Churchill Livingstone; 2021 [cited 2021 Jun 27]. Available from: https://doi.org/10.1016/j.

16. Elia R, Maruccia., M, Nacchiero., E, De Cosmo., A, Giudice., \& G. The ExpanderImplant Breast Reconstruction in the COVID Era: Which is the "'Unhappy" Tissue Expander Priority? Aesthetic Plast Surg [Internet]. Available from: https://doi.org/10.1007/s00266-021-023214

17. Crowley JS, Reghunathan M, Kadakia N, Barttelbort S, Gosman A. Financial Decisions and Reopening a Practice During the COVID-19 Pandemic. Ann Plast Surg [Internet]. 2021 May [cited 2021 June 27th];86(5S): S354-9. Available from: https://journals.lww.com/annalsplasticsur gery/Fulltext/2021/05003/Financial_Decisi ons_and_Reopening_a_Practice.2.aspx

18. Medscape. Medscape Plastic Surgeon Compensation Report 2021 [Internet]. [cited 2021 June 28th]. Available from:

https://www.medscape.com/slideshow/2 021-compensation-plastic-surgeon6013860\#19

19. Ligh, Cassandra A. M.D.; Lett, Lanair A. M.B.; Broach, Robyn B. Ph.D.; Enriquez, Fabiola A. B.A.; Jordan, Atasha M.D., M.B.A.; Percec, Ivona M.D., Ph.D.; Serletti, Joseph M. M.D.; Butler, Paris D. M.D., M.P.H. The Impact of Race, Age, Gender, Income, and Level of Education on Motivations to Pursue Cosmetic Surgery and Surgeon Selection at an Academic Institution, Plastic and Reconstructive Surgery: May 2020 - Volume 145 - Issue 5 - p 932e-939e DOI: 10.1097/P.R.S.0000000000006734 